\title{
Implications of genetic diversity in the improvement of silkworm Bombyx mori L.
}

\author{
Ximena Ruiz ${ }^{{ }^{*}}$, and Martha Almanza ${ }^{1}$ \\ ${ }^{1}$ Universidad del Cauca, Facultad de Ciencias Agrarias, 190003 Popayán, Cauca, Colombia. \\ *Corresponding author(xruiz@unicauca.edu.co).
}

Received: 24 March 2018; Accepted: 6 September 2018; doi:10.4067/S0718-58392018000400569

\begin{abstract}
Improvement programs depend on characterizing genetic resources, this process being the fundamental basis for determining the diversity and genetic divergence of such resources and thereby enabling a rigorous, efficient selection of the parentals that, through hybridization, will go on to enhance heterosis. The aim was to use the resulting hybrids to improve population mean with respect to genetic parameters used for the qualitative and quantitative traits that affect commercial natural silk production. Bombyx mori L. is a domesticated insect of global economic importance, mainly due to the production of natural silk but also for its relevance in rural agro-industry in tropical and subtropical regions. Non-textile uses currently being developed are also to the fore. These relate to such fields as science and academia, biomedicine, biotechnology, the pharmacological industry and cosmetics. With this in mind, the aim of the current article was to provide a general context for sericulture and in so doing give an overview of the silk production scenario nationally and go on to describe the importance of genetic diversity to silkworm breeding programs and to demonstrate how genetic drift, inbreeding, and artificial selection contribute to loss of genetic diversity in B. mori.
\end{abstract}

Key words: Cauca, genetic divergence, genetic improvement, sericulture.

\section{INTRODUCTION}

The silkworm (Bombyx mori L.) is an insect of great economic importance, bred in seasonal and tropical areas (Tazima, 1978). It has been so intensively domesticated that no B. mori populations remain in the wild (Yukuhiro et al., 2002), resulting in a lack of adaptation to adverse climatic conditions - especially the high temperatures prevalent in tropical countries (Kumari et al., 2011). It is the main source of silk ("the queen of natural fibers"), contributing around $90 \%$ of world production (ISC, 2014). Bombyx mori embraces a large number of geographic breeds, strains and hybrid lines (Furdui et al., 2014) classified (by origin, biological characteristics, and origin of germplasm banks) and preserved with the aim of gradually improving economic interest, to increase the benefits of sericulture and thereby boost silk production efficiency (Tavakolian, 2000).

Furdui et al. (2014) state that the diversity and structure of B. mori genetic resources can provide information to improve conservation, estimate inbreeding, and determine the consequences of overuse of lineages. In addition, they allow the optimization of breeding strategies that facilitate the selection of individuals with high genetic potential, emphasizing that nutritional, climatic (temperature, relative humidity, luminosity) and controlled sanitary conditions should be provided in breeding huts (Salehi et al., 2010; Talebi and Bakkappa, 2013; Neshagaran et al., 2016).

Evaluation of genetic diversity also permits an integral analysis of information on the genetic resources available for the development and structuring of research based on genetic improvement. Such resources can respond to the particular needs of tropical regions, where sericulture is a viable rural agroindustrial alternative, by guaranteeing the sustainable development of the chain. In this context, maintenance of diversity is a fundamental component in 
the long-term management strategies for the genetic improvement of B. mori (Buhroo et al., 2016a). The present review, therefore, highlights the importance of genetic diversity, conservation, maintenance and use of genetic resources of $B$. mori to obtain genetically superior hybrids.

\section{Sericulture generalities}

Bombyx mori is a domesticated insect that has been intensively used by Chinese farmers for silk production for approximately 5000 years (Xiang et al., 2005). According to Liu et al. (2010), its practice gradually spread to Korea, Japan, India, Brazil, and the rest of the world. In $139 \mathrm{BC}$, the world trade route was opened, from East China to the Mediterranean Sea, giving rise to the Silk Route. By 30 BC, the secret of silk production had already reached India and Japan, extending later to Europe and in colonial times reaching Latin America (Vietes et al., 2010).

The commercial production of silk led to construction of a production chain of global economic importance, involving sericulture activities that include agronomic management of the mulberry tree (Morus alba L.), obtaining silk thread, egg production, worm breeding, and the cocoon process. In this context, use of the thread predominates, whether artisan or industrial (textiles). Nonetheless, non-textile uses have great economic and scientific relevance, for example production of recombinant proteins (Tamura et al., 2000; Tomita et al., 2003), biomaterials for regenerative medicine, dental floss and medical suture material (Elices et al., 2011), and pharmacological products using fibroin nanoparticles, among others (Aznar, 2013). Additionally, B. mori is used in basic research areas such as microbiology, physiology and genetics (Willis et al., 1995).

Sericulture is developed mainly in rural or suburban areas. It is historically considered as an activity that complements agricultural and/or livestock production systems, benefitting small and medium producers who work as a family nucleus around silk production. Even though the activity does not require a significant initial investment, it does require that sericulturists provide controlled environmental and sanitary conditions during worm breeding and a feeding program based on quality mulberry (Pescio et al., 2008). Regarding quality and quantity of silk, excellent results are obtained in seasonal areas (Cifuentes and Sohn, 1998; FAO, 2003). In contrast, in tropical and subtropical areas, the low silk productivity is compensated by climatic conditions that enable it to be produced all year round (Pescio et al., 2008).

In the genetic resources of the silkworm, agro-climatic conditions entirely influence expression of the economic interest characteristics, whether genetic and biological (percentage of hatching and fecundity, duration of larval and fifth instar period, and rate of pupation) or productive (cocoon weight, relationship between shell and cocoon, percentage of raw silk, filament length (m) and yield of raw silk per box of worm eggs) (Thangavelu et al., 2000).

\section{Sericulture in Colombia}

The history of sericulture in Colombia goes back to 1868 and 1921 when the first attempts were made to introduce it as an economic alternative for families, since skilled labor was not required (García, 1970). Later, the Federation of Coffee Growers promoted and disseminated the sericulture activity among farmers for more than 20 years (1968-1990) (García, 1970; Cifuentes and Sohn, 1998; García et al., 2000). Sericulture flourished in the late 80s and early 90s of the last century, when the Korean government contributed to its promotion by establishing associative enterprises in order to obtain cocoons and industrially transform the silk thread to self-supply the Korean clothing industry and that of European countries (Cifuentes and Sohn, 1998; CORSEDA, 2003). However, these actions failed to have the desired impact due to the lack of adaptation of the imported larvae to tropical climes, and the withdrawal of support from the European Union due to the failings of the Colombian government as partner organization. On top of everything, international silk prices plummeted. It should be noted that in spite of the crisis, sericulturists sought alternatives such as associativity to reduce labor costs and continue working in silk production (CORSEDA, 2003).

The Sericulture Technological Development Center (Centro de Desarrollo Tecnológico de la Sericultura, CDTS), created in 1994, managed to maintain the cultivars of mulberry and keep the silkworm germplasm bank going on the El Pilamo experimental farm. The CDTS, in cooperation with the Colombian Agricultural Institute (Instituto Colombiano Agropecuario, ICA), created several hybrids of silkworm (Konsota and Pilamo I and II), of which Pilamo II is the only one currently marketed in Colombia. In 2004, the CDTS closed and in 2007, the Technological University of Pereira took over the facilities of the Center, renaming them as El Pilamo Experimental Farm and assuming custody of the maintenance and conservation of pure breeds, the production of eggs and the supply of mulberry cuttings (Cifuentes and Sohn, 1998; UTP, 2010). 
The Ministry of Agriculture and Rural Development and the departmental governorates have a set of strategies created to support and make visible the country's productive chains (Information System for Management and Performance of Chain Organizations [ISCO], Agronet platform, and Tángara Departmental Information System). However, sericulture is not registered at national level and therefore no documentation, indicators or statistical data are available to shed light on the perspectives or current state of sericulture in the country.

In the department of Cauca in the mid-1980s, sericulture activities comprised such associations as Sedas La Aradita, Colteseda, Hitesedas and Multisedas, and the Corporation for the Development of Sericulture in Cauca CORSEDA, which grouped local producers from the municipalities of Popayán, El Tambo, Timbio, Morales, and Piendamó (CORSEDA, 2003). Currently, COLTESEDA and CORSEDA continue to function. In 2011, the Agroarte Association was legally created in El Tambo, while independent producers are operating in Santander de Quilichao. The actors described above represented sericulture in Cauca. In 2016, they signed an act of intention to form the Promotional Committee of this activity in the department, and in 2017 approved the statutes of the Committee together with the constitution of the departmental Board. They also filed with the Ministry of Agriculture and Rural Development the documents necessary to continue, with a view to establishing agriculture at the national level, and thereby achieving recognition as a productive chain.

\section{Genetic resources}

The Bombyx genus has two distinct species, B. mori, of world economic importance, and B. mandarina M., the wild parental of B. mori. Other than Bombyx, the Bombycidae family is made up of 11 genera. Only Theophila and Ocinara, however, are close to it. It is therefore relevant to collect and preserve related species for use in breeding programs, thus expanding the genetic basis of $B$. mori through intergeneric crosses that provide the possibility of analyzing the transfer of genes useful as resistance to disease and tolerance to adverse agro-climatic conditions (FAO, 2003). The silkworm has germplasm banks associated with research centers located in China, India, Japan, Russia, Korea, and in Southeast Asian and European countries (Jingade et al., 2011). Currently, the Experimental Station for Sericulture and Agriculture in Vratsa, Bulgaria, and the Germplasm Resource Centers for sericulture in India stand out for their dedicated work in breeding programs.

The germplasm banks contain geographic breeds, genetic strains, lines and breeds, collected in different regions of the world, that have not gone through continuous processes of artificial selection, thus constituting reservoirs of biodiversity and a source of genes for breeding programs in the global scenario (Jingade et al., 2011; Sugnana et al., 2013); there are also more than 4000 strains available and maintained by constant mating (Jingade et al., 2011). These include univoltines, bivoltines and polyvoltines that exhibit wide variations in qualitative and quantitative characters (biological and productive). This allows the selection of distinct genotypes (Chandrakanth et al., 2014). A further 500 mutants are reported for qualitative characteristics such as: color in larvae and in the integument of the adults, skin marks and body shapes, colors and shapes of the cocoon, and physiological features such as diapause, moltinism, and characteristics such as proteins in the hemolymph and in the silk thread (sericin and fibroin), among others (Nagaraju et al., 2001). The information presented by the databases of germplasm banks is insufficient and codification of the accessions is defined by each bank. This situation makes it difficult to compare information and exchange accessions, which restricts the selection of potential parents and increases the possibility of duplicate materials. Another relevant aspect is that breeding programs are scarce, and in countries such as Spain, Japan, and Korea the research developed focuses on areas such as biochemistry, molecular biology, genomics, and genetic engineering, relegating the development of breeding programs to countries such as Bulgaria, India, and Iran.

Jingade et al. (2011) point out that the silkworm strains have been maintained in ex situ conditions, generating wide interpopulational genetic diversity and intrapopulational homogeneity, resulting in the loss of valuable genes through a process called inbred depression. The authors suggest that the process of conservation of genetic resources requires not only their acquisition and physical possession - it is important to ensure that the genetic traits are conserved in their original form and that the strains are protected from extinction.

\section{Genetic diversity}

The breeds of B. mori can be classified according to geographic origin, germplasm bank of origin, voltinism (number of cycles in $1 \mathrm{yr}$ ), and moltinism (number of molts per larval cycle). Geographically four breeds are identified: Chinese, 
Japanese, European, and tropical (Liu et al., 2010); according to the germplasm bank, four large groups are identified: Japanese, European, Spanish, and the hybrid group (Cifuentes and Sohn, 1998; Castejón, 2013); according to voltinism they can be univoltines, bivoltines and polyvoltines; and by moltinism they can be classified into trimolter, tetramolter, and pentamolter (Rodríguez et al., 2012).

The silkworm displays different types of voltinism: in seasonal areas, univoltines have one life cycle per year (with diapause) and the filament obtained from the cocoon is of excellent quality. Bivoltines have two cycles per year. The larval period is short. They are relatively resistant to high temperatures and humidities, and the filament is of good quality. Tropic and subtropical breeds meanwhile are multi or polyvoltines and have life cycles that continue throughout the year (with no diapause) (Cifuentes and Sohn, 1998). FAO (2003) notes that multivoltines are more resistant and tolerant to pathogen burden compared to bivoltines, but the amount and quality of silk they produce is poor. Nevertheless, they are valuable genetic reserves for improving the characteristics of seasonal worm breeds and for obtaining improved populations of $B$. mori. The number and duration of life cycles in B. mori are variable and related to the diapause, a strategy of dormancy that helps them to survive in adverse conditions and synchronizes the cycle of the individuals of a population with the environmental conditions and the availability of adequate resources (Amat, 2014). In this regard, Corbet (1999) points out that the number of larval stages varies from one species to another, with variation existing even within the same species. The same author also indicates that latitude, ambient temperature and photoperiod are important factors that influence the larval development of the insects.

Genetic diversity is a fundamental criterion of animal and plant breeding programs because inter- and intra-population variability can be determined by recognizing the number of different forms of genotype expression and presented as information repositories in the form of genes, alleles and chromosomes (Pérez, 2010); the greater the variability found, the greater is the opportunity to find characteristics of interest, which in turn make up the genetic base, from which purpose-made, specific selection processes can be carried out for the objectives of an improvement program (Nezhad et al., 2010; Anuradha et al., 2012; Kumari and Tripathi, 2017).

Genetic divergence considers the degree of inter- and intra-populational genetic variation of geographically separated species (Jingade et al., 2011), determining how broad or narrow the genetic information is. It may be minimal (meaning that the difference is in a single characteristic morphologically expressed) or it can be of considerable magnitude to allow the integration of different systems for a specific function (Kwiatkowska and López, 2000).

Analysis and characterization of the divergence in a population allows the identification of contrasting progenitors or genotypes. These can give rise to hybrid combinations, descendants with high hybrid vigor, or transgressive individuals that can originate hybrids or commercial varieties (Lagos et al., 2003); it also allows estimation of rates of variation among genotypes, making it an effective tool for calculating increases in genetic potential in breeding programs (Nagaraju and Singh, 1997). Therefore, making a selection of genetically pure and divergent parental, knowing the genetic distances, and the nature and magnitude of the genetic diversity that exists among the available breeds of B. mori are critical activities because they determine the improvement of quantitative and qualitative traits linked to the production of cocoons (Sen et al., 1996; Nagaraju and Goldsmith, 2002; Maqbool et al., 2015; Kumari and Tripathi, 2017). Maqbool et al. (2015) studied genetic divergence by analyzing quantitative traits in B. mori bivoltines and the results showed that $99.4 \%$ of the total divergence is represented by quantitative traits such as duration of fifth instar, total duration of larval cycle, weight of mature silk gland, cocoon weight, cocoon yield/10000 larvae, and denier.

The relationship between genetic diversity and geographic origin was studied by Ahmad and Borah (1999). They found a relative contribution of the different genotypes to the formation of different clusters, revealing that there is no parallelism between the two criteria. Farooq et al. (2005), Zanatta et al. (2009) and Nezhad et al. (2010) showed in their research that B.mori genotypes with different geographical origin were grouped in the same cluster, while genotypes of similar origin were grouped in different clusters, suggesting differences both biological and in performance. Maqbool et al. (2015) and Falconer and Mackay (1996) indicate that these results can be explained by the fact that populations, over time, have been differentiated by genetic drift and continuous artificial selection, being able to adapt morphologically and/ or physiologically to specific agroclimatic conditions which eventually led to divergence. Bindroo and Moorthy (2014) suggest that variation is affected by other evolutionary forces such as effective size of the population, mutation, gene flow, inbreeding depression and natural selection. In silkworm, it could be affected by domestication, genetic drift, inbreeding, and the breeding systems used. 


\section{Causes that affect genetic diversity of $B$. mori.}

Domestication is a recent evolutionary event that may have generated alterations and diversification in the structure of populations (Sakudoh et al., 2011). Goldsmith (2009) indicates that B. mori has been subjected to intense and constant artificial selection, reducing its genetic base. According to Brown (1988), an enhancer selects elite parentals to obtain superior progenies, but the continuous use of the best genotypes reduces the genetic base, since only the alleles that come from these parents are available. Bindroo and Moorthy (2014) suggest that reduction also occurs when the breeder introduces wild-type alleles to their target genotype, because the process of "eliminating" "undesirable" alleles must be begun.

Genetic drift considers the change of allelic frequencies in a population across generations. An allele can replace another, fixate and ensure that the replaced allele no longer expresses itself (Eguiluz, 1988). The smaller a population, the greater will be the changes in allelic frequencies. These cause a greater loss of genetic variation (an increase in homozygosity) in the population, reducing its biological efficacy and evolutionary potential (Frankham et al., 2002; Hallibustron, 2004). In B. mori, domestication may also have generated drift of characters of interest related to the ability to acquire thermotolerance. This vulnerability is more pronounced in bivoltine breeds, compared with multivoltines, suggesting that lack of thermotolerance is a factor responsible for the poor results in bud production in univoltine and bivoltine breeds under tropical conditions (Kumari et al., 2011).

Inbreeding is the crossing between related genotypes: the closer the kinship, the greater the percentage of consanguinity in the resulting offspring (Ralls et al., 2013). Ocampo and Cardona (2013) state that inbreeding reduces intra-populational genetic variability; it increases the probability of inheriting alleles associated with genetic defects, and decreases heterozygosity. Increased homozygosity results in greater expression of deleterious recessive alleles (partial dominance hypothesis) (Reed, 2008) and/or less opportunity to express the superiority of the heterozygote (overdominance hypothesis) generating direct genetic consequences, including its effect on the intensity of inbreeding depression and the fractioning of genetic diversity (Charlesworth et al., 1979; Hamrick and Godt, 1990; Charlesworth and Charlesworth, 1995). However, inbreeding also has advantages and has been used to "purify breeds", "concentrate" genes of interest, and increase the uniformity of offspring (Gjedrem, 2005).

Jingade et al. (2011) show that pure lines of B. mori are maintained in germplasm banks as a genetic basis with inbreeding for one or more qualitative and/or quantitative traits. The same authors define a pure parental line as inbreeding stock that is crossed with other lines to produce a hybrid and exploit the heterosis or hybrid vigor of the characters that satisfy the needs of the breeders. Furthermore, they indicate that the pure inbred lines are developed by means of crossing between two breeds that show excellent characters and the subsequent mating between siblings for seven or more generations, making a selection from the progeny in each cycle and keeping them as separate families.

Sánchez (2013) shows that although there is no method for eliminating consanguinity in animal breeding programs and in commercial farms, strategies should be sought to control the negative effects of inbreeding depression: for example, establishing an identification system for each genotype and its offspring (including a code for each one), that allows a pedigree as complete as possible to be obtained by genotype, as well as performing matings between different breeds, to obtain maximum levels of heterosis.

\section{Genetic diversity and molecular markers}

Molecular diversity studies evaluate the genetic structure and complex components specific to each species, to overcome limitations presented using morphological and biochemical markers (Glaszmann et al., 2010). For Buhroo et al. (2018a), a molecular marker is a gene or DNA sequence with a known location on a chromosome, or a protein sequence used to identify individuals or species.

In this context, it is worth noting that current trends on applying DNA marker techniques in insect studies show that mitochondrial DNA (mtDNA), microsatellites or simple sequence repeats (SSR), random amplified polymorphic DNA (RAPD), inter simple sequence repeats (ISSR), expressed sequence tag (EST), amplified fragment length polymorphism (AFLP), restriction fragment length polymorphism (RFLP), as well as microarray and single nucleotide polymorphism (SNP) analyzes that are both increasingly popular in detecting complete genome polymorphisms quickly and economically, have all contributed significantly to understanding the genetic basis and - in the mapping of genes of economic importance - the medical basis as well as quantitative trait loci in insects (Tomas et al., 2008). 
In the lepidoptera order, the progress that exists on the biology and genetics of B. mori stands out: $B$ mori is considered as the most advanced among the species that make up this order, a situation likely strengthened with the publication of the genome sequence of B. mori in 2008 by the International Silkworm Genome Consortium.

This has allowed, during the last decade, the identification and development of markers with such potential applications as the identification and characterization of genetic stocks (facilitating the study of diversity and the estimation of the degree of kinship that exists within the germplasm banks); molecular map construction; marker-assisted selection; the identification of quantitative trait loci (QTL); the positional cloning of visible mutations; and the construction of BAC libraries (Zhan et al., 2009; Sreekumar et al., 2011; Venkatesh and Chikkaswamy, 2017; Buhroo et al., 2018b).

Buhroo et al. (2016b) indicate that markers are necessary tools that can further accelerate silkworm improvement. For this reason, the large, carefully maintained collections of $B$. mori are valuable resources that must be exploited to their full potential. Likewise, Radjabi et al. (2012) and Wani et al. (2013) state that the identification of biodiversity, and in turn, the detection and exploitation of DNA sequence polymorphisms have potential applications in programs of genetic improvement of animals and plants. Ma and Xia (2015) meanwhile state that currently the development and application of genome editing tools in B. mori would significantly improve the level and scope of research fundamental to ensuring the sustainable development of sericulture.

Chandrakanth et al. (2014) suggest as the best option the selection of parents, for developing elite hybrids, based on measurement of phenotypic traits and genetic variation (DNA profiles), since the traits express variation on interacting with the environment and profiles would produce reliable estimates of diversity and genetic polymorphism.

Regarding the specific use of markers, Moorthy et al. (2013) indicate that RAPD can discriminate and differentiate between $B$. mori breeds depending on the silk content and that using voltinism characteristics would allow the identification, conservation and subsequent use in improving performance and maximizing productivity in breeding programs. Pereira et al. (2013) meanwhile assert that analysis with RAPD has proved to be an efficient technique for detecting variability and can further be used to identify materials susceptible to the BmNPV baculovirus. Elsewhere, Awasthi et al. (2008) state that specific primers, such as RFLP and sequence-tagged sites (STS), and non-specific primers, such as RAPD and ISSR, can be used effectively to decipher genetic relationship problems in both improved populations and B. mori mutants.

Miao et al. (2007) add that among the group of markers, microsatellites in particular represent an important tool as they are highly polymorphic and useful when creating linkage maps. They are also popular in the area of population genetics (Sharma et al., 2007), while Kim et al. (2010) indicate that they are potentially useful for discriminating B. mori strains. Chandrakanth et al. (2014) likewise state that they have the ability to estimate the diversity between bivoltines and polyvoltines strains. They also show a relevant use in marker-trait association, in the elaboration of genetic profiles, and in the identification of similarity patterns. They are furthermore an invaluable method for addressing issues related to breeder rights, genetic homozygosity, marker-assisted selection and definition of crossing strategies with divergent parents. Moreover, Chandrakanth et al. (2015a) report the identification of specific SSRs linked to thermotolerance, located on chromosome 8 , although they emphasize that this characteristic is polygenic and there may thus be associated markers in other chromosomes.

In conclusion, it must be emphasized that the evaluation of genetic diversity within a species and/or a population is a prerequisite to developing a program of management, conservation and sustainable improvement of plants, animals and insects. Molecular markers can be used as a working tool, having advantages over morphobiochemical markers, being stable, environmentally independent, and appropriate for detecting intra- and interspecific genetic variation, thereby optimizing the use of resources (Buhroo et al., 2018b).

\section{Improvement in B. mori}

Animal genetic improvement applies biological and mathematical principles in order to find optimal strategies for taking advantage of existing genetic variation to maximize the genetic merit of the species (Notter, 2013). The two primary tools of genetic improvement are selection of parentals with traits of interest and mating systems (Matz, 2011). The genetic improvement of $B$. mori involves social and economic aspects that affect the results of the breeding process developed for each country. According to Vaez et al. (2011), the main causes that increase success in B. mori are: 1) robust breeding methods based on quantitative genetic theory; 2) continuous and regular increase of heterosis for economically important characters; and 3) development of information processing systems. 
Tzenov (2003) indicates out that the research on B. mori during the 20th century was directed to studies on Genotype $\times$ Environment interaction using the potency of the hybrid vigor phenomenon as the main strategy to meet the needs of raw silk production for the textile industry. The above implied studying the expression of heterosis in $\mathrm{F}_{1}$, the expression of positive transgressions in $\mathrm{F}_{2}$, combinatorial ability, genetic correlations and regressions, heritability of the main qualitative and quantitative traits, use of improved inbred lines, use of parthenogenesis and androgenesis, and improvement of seasonal hybrids and lines (summer-autumn). It would make it possible to obtain excellent yields in egg production, larval breeding, production and quality of cocoons and raw silk, and the ability to adapt to different environmental conditions (Lea, 1993; Tzenov, 2003; Vaez et al., 2011).

Genetic improvement in B. mori continues in the $21^{\text {st }}$ century and is also focused on obtaining high yielding hybrids, production of silk limited by sex (larvae) and selection of parental breeds with different cocoon color for the production of hybrids (Tzenov, 2003). Countries such as India work on the productive potentialities of bi and polyvoltine parental breeds; with the former, the aim is to improve the quality of the silk and participate in international markets. The objective of the latter is to evaluate tolerance to fluctuating environmental conditions in tropical regions, especially at high temperature, highlighting the need to develop genotypes of B. mori with genetic plasticity (thermotolerance and stability) to counter the adverse climatic effects on silk production (Dayananda et al., 2013; Chandrakanth et al., 2015b; 2016).

The European Commission (Comisión Europea, 2014), meanwhile, indicates that there are applications of silk thread on the way for biomedicine and biotechnology, such as the production of natural and recombinant proteins (fibroin) for the scalable production of new skin and nerve tissues, dermatological and cosmetic products, anti-inflammatory agents, and also as a vector in the creation of new vaccines and antibodies. It suggests that the market for sericulture activity is broad. Work with genetic resources of $B$. mori is therefore very relevant.

\section{CONCLUSIONS}

Studying diversity and genetic divergence in animal breeding programs is vitally important because it makes it possible to identify and determine the genetic variability within the target population and to efficiently select ideal parentals for obtaining genotypes with high hybrid vigor. Selection, breeding, and proper maintenance of Bombyx mori materials in germplasm banks allow the preservation of the characteristics of the breeds and, in addition, avoid the negative effects of inbreeding depression. A universal coding system for B. mori genetic resources is required to avoid duplication and provide an efficient tool for sharing information between institutions and research centers that work on breeding programs. Passport data should be complete and if possible, information shared about research processes focused on the phenotypic characterization of the materials, and to have reference points regarding the response that the genotypes might have under particular agroclimatic conditions. Sericulture needs policies and programs that optimize the process of silk production in terms of quantity and quality in order to strengthen competitiveness, innovation and the opportunity to participate in national and international markets, becoming an alternative means for small and medium producers to increase their economic incomes to benefit the family unit.

\section{ACKNOWLEDGEMENTS}

The authors thank the scientific and financial support to the project "Technological development for the obtention of organic and innovative natural silk products" carried out by the University of Cauca and financed by the General System of Royalties.

\section{REFERENCES}

Ahmad, T., and Borah, P. 1999. Genetic diversity in glutinous rice germplasm of Assam. Oryza 36(1):74-75.

Amat, M. 2014. Regulación de la diapausa y emergencia del ectoparásito aviar Carnus hemapterus: factores abióticos, microclima y mecanismos implicados. PhD Tesis. Universidad de Murcia, Departamento de Sanidad Animal, Murcia, España.

Anuradha, J., Somasundaram, P., Vishnupriya, S., and Manjula, A. 2012. Storage protein-2 as a dependable biochemical index for screening germplasm stocks of the silkworm Bombyx mori (L). The Albanian Journal of Agricultural Sciences 11:141-148. 
Awasthi, A.K., Kar, P.K., Srivastava, P.P., Rawat, N., Vijayan, K., Pradeep, A.R. et al. 2008. Molecular evaluation of bivoltine, polyvoltine and mutant silkworm (Bombyx mori L.) with RAPD, ISSR and RFLP-STS markers. Indian Journal of Biotechnology 7:188-194.

Aznar, S. 2013. El gusano de seda Bombyx mori (Linneo, 1758) (Lepidoptera: Bombycidae) como plataforma de producción de proteínas naturales y recombinantes. Aplicaciones en Biotecnología e Ingeniería de Tejidos. PhD Tesis. Universidad de Murcia, Departamento de Zoología y Antropología Física, Murcia, España.

Bindroo, B., and Moorthy, S. 2014. Genetic divergence, implication of diversity and conservation of silkworm Bombyx mori. International Journal of Biodiversity 2014:564850. doi:10.1155/2014/564850.

Brown, A. 1988. The genetic diversity of germplasm collections. Proceedings of the Workshop on the Genetic Evaluation of Plant Genetic Resources. Canada Research Branch, Toronto, Canada.

Buhroo, Z., Bhat, M., Ganai, N., Kamili, A., Bali, G., and Aziz, A. 2018a. Molecular basis of growth and aging in model organisms with special reference to the silkworm Bombyx mori: A review. Journal of Entomology and Zoology Studies 6(4):740-751.

Buhroo, Z., Bhat, M., Ganai, N., Kamili, A., Bali, G., and Aziz, A. 2018b. An efficient protocol for the inter-simple sequence repeat (ISSR) marker approach in population genetic studies. Journal of Entomology and Zoology Studies 6(4):597-600.

Buhroo, Z., Ganai, N., and Bhat, M. 2016a. Molecular Marker Systems with special reference to the Silkworm Bombyx mori L. International Journal of Bioassays 5(11):5025-5040. doi:10.21746/ijbio.2016.11.007.

Buhroo,Z., Malik, M., Ganai, N., Kamili, A., and Bhat, B. 2016b. Comparative performance and genetic polymorphism in some potential silkworm Bombyx mori L. genotypes. Journal of Cell and Tissue Research 16(3):5911-5920.

Castejón, J. 2013. Amarilla española número 2, "Sierra Morena”. Boletín de la Asociación Entomológica de Asturias Nr 5. Vol. 1.3 p. Asociación Española para la Recuperación, Conservación y Estudio del Gusano de Seda Autóctono (AERCEGSA), Salamanca, España.

Cifuentes, C., y Sohn, K. 1998. Manual técnico de la sericultura, cultivo de la morera y cría del gusano de seda en el trópico. Fondo Editorial de Risaralda, Risaralda, Colombia.

Comisión Europea. 2014. Un proyecto pionero en la cría del gusano de seda vincula los ámbitos de la biomedicina y la biotecnología en Murcia. Available at http://ec.europa.eu/regional_policy/es/projects/spain/pioneer-project-in-silk-farmingconnects-biomedicine-with-biotechnology-in-murcia (accessed February 2017).

Corbet, P. 1999. Dragonflies, behavior and ecology of Odonata. Cornell University Press, Ithaca, New York, USA.

CORSEDA. 2003. Sistematización de experiencias locales proyecto de apoyo al desarrollo de la microempresa rural PADEMERla influencia de la integración de productores y artesanos en el desarrollo de la corporación para el desarrollo de la sericultura del Cauca. Corporación para el Desarrollo de la Sericultura (CORSEDA), Popayán, Colombia.

Chandrakanth, N., Moorthy, S., Anusha, P., Dayananda, S., Kumar, V., and Bindroo, B. 2014. Evaluation of genetic diversity in silkworm Bombyx mori L. strains using microsatellite markers. International Journal of Biotechnology and Allied Fields 2(3):73-83.

Chandrakanth, N., Moorthy, S., Ponnuvel, K., and Sivaprasad, V. 2015b. Screening and classification of mulberry silkworm, Bombyx mori based on thermotolerance. International Journal of Industrial Entomology 31(2):115-126. doi:10.7852/ijie.2015.31.2.115.

Chandrakanth, N., Moorthy, S., Rekha, M., and Sivaprasad, V. 2016. Stability and path analysis for yield and related traits in silkworm, Bombyx mori L., reared under stress conditions. Genetika 48(1):271-284. doi:10.2298/GENSR1601271C.

Chandrakanth, N., Moorthy, S., and Sivaprasad, V. 2015a. Identification of microsatellite markers linked to thermotolerance in silkworm by bulk segregant analysis and in silico mapping. Genetika 47(3):1063-1078.

Charlesworth, D., and Charlesworth, B. 1995. Quantitative genetics in plants: the effect of the breeding system on genetic variability. Evolution 49(5):911-920.

Charlesworth, D., Charlesworth, B., and Strobeck, C. 1979. Selection for recombination in self-fertilising species. Genetics 93:237-244.

Dayananda, S., Varadaraja, P., Balavenkatasubbaiah, M., Chandrashekarana, K., Kumar, S., and Bindroo, B. 2013. New breeding resource material for the development of polyvoltine breeds of silkworm, Bombyx mori L., tolerant to high temperature. International Journal of Plant, Animal and Environmental Sciences 3(4):86-91.

Eguiluz, P. 1988. Distribución natural de los pinos en México. Nota Técnica N 1. 6 p. Centro de Genética Forestal, A.C. Chapingo, México.

Elices, M., Pérez, J., Plaza, G., y Guinea, G. 2011. Usos médicos de la seda. Investigación y Ciencia. Nr 419. p. 28-35.

Falconer, D.S., and Mackay, T.F. 1996 Introduction to quantitative genetics. $4^{\text {th }}$ ed. Longmans Green, Harlow, Essex, UK.

FAO. 2003. Conservation status of sericultural germplasm resources in the World. I. Conservation status of mulberry (Morus spp.) genetic resources in the World. Food and Agriculture Organization of the United Nations (FAO), Rome, Italy. Available at http://www.fao.org/3/a-ad108e/ad108e00.htm\#Contents (accessed January 2017).

Farooq, M., Sofi, A., Malik, G., Malik, M., Kukiloo, F., Raja, T., et al. 2005. Studies on the genetic diversity in mulberry silkworm, Bombyx mori L. p. 5-11. In Annual Research Report, 2005-2006. 37th Research Council Meeting, Sher-e-Kashmir University of Agricultural Sciences and Technology of Jammu (SKUAST), Jammu, Division of Sericulture, Mirgund, Bramulla, Kashmir. 
Frankham, R., Ballou, J., and Briscoe, D. 2002. Introduction to conservation genetics. Cambridge University Press, Cambridge, UK.

Furdui, E., Marghitas, L., Dezmirean, D., Pasca, I., Pop, I., Erler, S., et al. 2014. Genetic characterization of Bombyx mori (Lepidoptera: Bombycidae) breeding and hybrid lines with different geographic origins. Journal of Insect Science 14(211):1-6. doi:10.1093/jisesa/ieu073.

García, F. 1970. Posibilidades de la industria de la seda en la zona central cafetera de Colombia. Revista Cafetera de Colombia 19(148):77-100.

García, C., Krause, H., y Perea, B. 2000. Estudio de adaptación de materiales promisorios de morera en la zona central cafetera de Colombia. Cenicafé 51(1):54-65.

Gjedrem, T. 2005. Selection and breeding programs in aquaculture. Springer Dordrecht, New York, USA.

Glaszmann, J., Kilian, B., Upadhyaya, H., and Varshney, R. 2010. Accessing genetic diversity for crop improvement. Current Opinion in Plant Biology 13(2):167-173.

Goldsmith, M. 2009. Recent progress in silkworm genetics and genomics. p. 25-48. In Molecular biology and genetics of the Lepidoptera. CRC Press, Boca Raton, Florida, USA.

Hallibustron, R. 2004. Introduction to population genetics. Pearson Education, Upper Saddle River, New Jersey, USA.

Hamrick, J., and Godt, M. 1990. Allozyme diversity in plant species. p. 43-63. In Brown, A.H.D., Clegg, M.T., Kahler, A.L., and Weir, B.S. (eds.) Plant population genetics, breeding, and genetic resources. Sinauer Associates, Sunderland, Massachusetts, USA.

ISC. 2014. Tipos de seda. International Sericultural Commission (ISC), Madiwala, Bangalore, India. Available at http://inserco.org/en/types_of_silk (accessed March 2017).

Jingade, A., Vijayan, K., Somasundaram, P., Srinivasababu, G., and Kamble, C. 2011. A review of the implications of heterozygosity and inbreeding on germplasm biodiversity and its conservation in the silkworm Bombyx mori. Journal of Insect Science 11(1):1-16. doi.org/10.1673/031.011.0108.

Kim, K., Kang, P., Lee, K., Oh, H., Kim, M., Kim, K., et al. 2010. Microsatellite analysis of the silkworm strains (Bombyx mori): high variability and potential markers for strain identification. Genes and Genomics 32:532-543. doi:10.1007/s13258-010-0066-x.

Kumari, S., Subbarao, S., Misra, S., and Murty, U. 2011. Screening strains of the mulberry silkworm, Bombyx mori, for thermotolerance. Journal of Insect Science 11(1):1-14. doi.org/10.1673/031.011.11601.

Kumari, A., and Tripathi, N. 2017. Genetic diversity studies in six bivoltine races of Bombyx mori L., based on phenotypic characters. International Journal Advanced Research 5(1):1048-1054. doi:10.21474/IJAR01/2851.

Kwiatkowska, T., y López, R. 2000. Ingeniería genética y ambiental, problemas filosóficos sociales de la biotecnología. p. 153168. Consejo Nacional de Ciencia y Tecnología (Conacyt)-Plaza y Valdés, México.

Lagos, T., Criollo, H., y Checa, O. 2003. Divergencia genética y heterosis. Revista de Ciencias Agrícolas 20(1):10-26.

Lea, H. 1993. Principles and techniques of silkworm breeding. Silkworm breeding. Haghshenass Press, United Nations, New York, USA.

Liu, Y.Q., Qin, L., Li, Y.P., Wang, H., Xia, R.X., Qi, Y.H., et al. 2010. Comparative genetic diversity and genetic structure of three Chinese silkworm species Bombyx mori L. (Lepidoptera: Bombycidae), Antheraea pernyi Guérin-Meneville and Samia cynthia ricini Donovan (Lepidoptera: Saturniidae). Neotropical Entomology 39(6):967-976.

Ma, S., and Xia, Q. 2015. Genome editing brings a new era of silkworm research. Science of Sericulture 41:195-230.

Maqbool, A., Dar, H., Ahmad, M., Malik, G., Zaffar, G., and Mir, S. 2015. Genetic divergence in some bivoltine silkworm (Bombyx mori L.) breeds. Scientific Research and Essays 10(11):381-385. doi:10.5897/SRE2015.6253.

Matz, B. 2011. Crossing, grading and keeping pure: animal breeding and exchange around 1860. Revista Endeavour 35:7-17. doi:10.1016/j.endeavour.2010.12.001.

Miao, X., Li, M., Dai, F., Lu, C., Goldsmith, M., and Huang, Y. 2007. Linkage analysis of the visible mutations Sel and Xan of Bombyx mori (Lepidoptera: Bombycidae) using SSR markers. European Journal Entomology 104:647-652.

Moorthy, S., Chandrakanth, N., Rao, A., Kumar, V., and Bindroo, B. 2013. Genetic diversity analysis using RAPD marker in some silkworm breeds of Bombyx mori L. Annals of Biological Research 4(12):82-88.

Nagaraju, J., and Goldsmith, M. 2002. Silkworm genomics-progress and prospects. Current Science 83:415-425.

Nagaraju, J., Klimenko, V., and Pierre, C. 2001. The silkworm, Bombyx mori: A model genetic system. Encyclopedia of Genetics. Eric C.R. Reeve \& Fitzroy Dearborn Publishers, London, England.

Nagaraju, J., and Singh, L. 1997. Assessment of genetic diversity by DNA profiling and its significance in silkworm, Bombyx mori. Electrophoresis 18:1676-1681.

Neshagaran, R., Seidavi, A., and Gharahveysi, S. 2016. A review on correlation, heritability and selection in silkworm breeding. Journal of Applied Animal Research 44(1):9-23. doi:10.1080/09712119.2014.987289.

Nezhad, M., Mirhosseini, S., Garahveysi, S., Mavvajpour, M., Seidevi, A., and Naserani, M. 2010. Genetic diversity and classification of 51 strains of silkworm, Bombyx mori (Lepidoptera: Bombycidae) germplasm based on larval phenotypic data using Ward's and UPGMA methods. African Journal of Biotechnology 9(39):6594-6600.

Notter, D. 2013. Breeding of animals. Encyclopedia of Biodiversity. $2^{\text {nd }}$ ed. Oxford, UK. 
Ocampo, R., y Cardona, H. 2013. La endogamia en la producción animal. Revista Colombiana Ciencia Animal 5(1):463-479.

Pereira, N., Munhoz, R., Bignotto, T., Bespalhuk, R., Garay, L., Saez, C., et al. 2013. Biological and molecular characterization of silkworm strains from the Brazilian germplasm bank of Bombyx mori. Genetics and Molecular Research 12(2):21382147. doi.org/10.4238/2013.June.28.1.

Pérez, L. 2010. Diversidad genética de chiles Capsicum spp., del estado de Tabasco, México. PhD Tesis. Instituto Politécnico Nacional, Escuela Nacional de Ciencias Biológicas, México D.F.

Pescio, F., Zunini, H., Basso, C., Divo de Sesar, M., Frank, R., Pelicano, A., et al. 2008. Sericicultura: Manual para la producción . Universidad de Buenos Aires e INTI, Buenos Aires, Argentina.

Radjabi, R., Sarafrazi, A., Tarang, A., Kamali, K., and Tirgari, S. 2012. Intraspecific biodiversity of Iranian local races of silkworm Bombyx mori by ISSR (Inter-Simple Sequence Repeat) molecular marker. World Journal of Zoology 7(1):17-22. doi:10.5829/idosi.wjz.2012.7.1.56434.

Ralls, K., Frankham, R., and Ballou, J. 2013. Inbreeding and outbreeding. In Encyclopedia of Biodiversity. $2^{\text {nd }}$ ed. Academic Press, Oxford, UK.

Reed, D. 2008. The effects of population size on population viability: from mutation to environmental catastrophes. p. 16-35. In Carroll, S., and Fox, C. (eds.) Conservation biology: Evolution in action. Oxford University Press, New York, USA.

Rodríguez, O., Vargas, M., Ventura, M., Martínez, M., Rodríguez, M., y Ehsan, M. 2012. Manual de sericultura en Hidalgo (Principios Básicos). Universidad Politécnica de Francisco I. Madero (UPFIM), Consejo Nacional de Ciencia y Tecnología (CONACyT), Fondo Mixto de Fomento a la Investigación Científica y Tecnológica-CONACYT (FOMIX-HGO), Hidalgo, México.

Sakudoh, T., Nakashima, T., Kuroki, Y., Fujiyama, A., Kohara, Y., Honda, N., et al. 2011. Diversity in copy number and structure of a silkworm morphogenetic gene as a result of domestication. Genetics 187(3):965-976. doi:10.1534/genetics.110.124982.

Salehi, M., Mirhosseini, S., Gharahveysi, S., Mavvajpour, M., and Seidavi, R. 2010. Evaluation of 37 economically important traits from 51 strains of the silkworm Bombyx mori and their relationships. Journal of Food, Agriculture and Environment 8(2):924-929.

Sánchez, J. 2013. Consanguinidad: Costo oculto para la ganadería de leche. 8 p. Genética Selecta Medellín, Colombia.

Sen, S., Nair, B., Das, S., Roy, G., Gosh, B., Rao, P., et al. 1996. Relationship between the degree of heterosis and genetic divergence in the silkworm, Bombyx mori L. Sericologia 36(2):215-229.

Sharma, P., Grover, A., and Kahl, G. 2007. Mining microsatellites in eukaryotic genomes. Trends Biotechnology 25:490-498. doi:10.1016/j.tibtech.2007.07.013.

Sreekumar, S., Ashwath, S., Slathia, M., Kumar, S., and Qadri, S. 2011. Detection of a single nucleotide polymorphism (SNP) DNA marker linked to cocoon traits in the mulberry silkworm, Bombyx mori (Lepidoptera: Bombycidae). European Journal of Entomology 108:347-354.

Sugnana, S., Misra, S., Srinivasa, M., and Suryanarayana, U. 2013. Assessment of genetic divergence with self-organizing maps (SOM) in silkworm Bombyx mori L., (Lepidoptera: Bombycidae) genotypes. Biotechnology 12(5):189-201. doi:10.3923/ biotech.2013.189.201

Talebi, E., and Bakkappa, S. 2013. Appraisal of eighteen silkworm Bombyx mori L., genotypes using pre and post cocoon characters. Science International 1(5):118-123. doi:10.5567/sciintl.2013.118.123.

Tamura, T., Thibert, C., Royer, C., Kanda, T., Abraham, E., Kamba, M., et al. 2000. Germline transformation of the silkworm Bombyx mori L. using a piggyBac transposon-derived vector. National Biotechnology 18:81-84. doi:10.1038/71978.

Tavakolian, J. 2000. An approach to native animal and poultry genetics reserves in Iran. Animal Science Research Institute, Department of Animal Science, Karaj, Iran.

Tazima, Y. 1978. Radiation mutagenesis of the silkworm. p. 1-3. In The silkworm: an important laboratory tool. Kodansha Ltd., Tokyo, Japan.

Thangavelu, K., Sinha, R., Mahadevamurthy, T., Radha, S., Kumaresan, P., Mohan, B., et al. 2000. Catalogue on silkworm Bombyx mori L., germplasm. CSGRC, Hosur, India.

Tomas, A., Flores, I., Fernandes, P., Cayuela, M., Maraver, A., Tejera, A., et al. 2008. Telomerase reverse transcriptase delays aging in cancer-resistant mice. Cell 135:609-622.

Tomita, M., Munetsuna, H., Sato, T., Adachi, T., Hino, R., Hayashi, M., et al. 2003. Transgenic silkworms produce recombinant human type III procollagen in cocoons. Nature Biotechnology 21:52-56. doi:10.1038/nbt771.

Tzenov, P. 2003. Conservation status of silkworm germplasm resources in Bulgaria. In Conservation status of silkworm germplasm resources in the World. II. In XIX International Sericultural Commission Congress, Bangkok, Thailand. 21-25 September. International Sericultural Commission, Bangalore, Karnataka, India.

UTP. 2010. Reseña histórica. Universidad Tecnológica de Pereira (UTP), Pereira, Colombia. Available at http://www.utp.edu . co/granjaelpilamo/resena-historica (accessed March 2017).

Vaez, E., Seidavi, A., and Lavvaf, A. 2011. Hybrid and hybridization as appropriate tool for silkworm production improvement: A review. Journal of Food, Agriculture and Environment 9(3):992-997.

Venkatesh, N., and Chikkaswamy, K. 2017. Ideas and innovations in technology. Analysis of genetic diversity and relationships of silkworm varieties using molecular marker. International Journal of Advanced Research 3(1):482-488. 
Vietes, C., Basso, C., y Zunini, H. 2010. Aporte a la comprensión de la situación de la sericicultura en la Argentina y en Latinoamérica. INTI-Imprenta, Buenos Aires, Argentina.

Wani, S., Bhat, M., Buhroo, Z., Ganai, M., and Majid, N. 2013. Role of molecular markers in silkworm improvement. International Journal of Recent Scientific Research 4(5):515-523.

Willis, J., Wilkins, A., and Goldsmith, M. 1995. A brief history of Lepidoptera as model systems. p. 1-20. In Goldsmith, M., and Wilkins, A. (eds.) Molecular model systems in the Lepidoptera. Cambridge University Press, Cambridge, UK.

Xiang, Z., Huang, J., Xia, J., and Lu, C. 2005. Biology of sericulture. China Forestry Publishing House, Beijing, China.

Yukuhiro, K., Sezutsu, H., Masanobu, I., Shimizu, K., and Banno, Y. 2002. Significant levels of sequence divergence and gene rearrangements have occurred between the mitochondrial genomes of the wild mulberry silkmoth, Bombyx mandarina, and its close relative, the domesticated silkmoth, Bombyx mori. Molecular Biology Evolution 19(8):1385-1389. doi:10.1093/oxfordjournals.molbev.a004200.

Zanatta, D., Bravo, J., Barbosa, J., Munhoz, R., Fernandez, F., and Maria, A. 2009. Evaluation of economically important traits from sixteen parental strains of the silkworm, Bombyx mori L. (Lepidoptera: Bombicidae). Neotropical Entomology 38(3):327-331. doi:10.1590/S1519-566X2009000300005.

Zhan, S., Huang, J., Guo, Q., Zhao, Y., Li, W., Miao, X., et al. 2009. An integrated genetic linkage map for silkworms with three parental combinations and its application to the mapping of single genes and QTL. BMC Genomics 10:389-404. 